\title{
The Analysis of Recovery Implementation for Domestic Violence Victims
}

\author{
Yudha Suchmasasi ${ }^{{ }^{*}}$; Bambang Utoyo Sutiyoso ${ }^{2}$; Ani Agus Puspawati ${ }^{3}$
}

Published online: 5 December 2021

\begin{abstract}
In Indonesia, the most common forms of domestic violence experienced are physical, sexual, psychological and economic neglect. As a result, it can cause physical and psychological injuries. Therefore, it is important to pay attention to the victim's recovery in order to strengthen the victim to be more empowered, both physically and psychologically. This article aims to describe and analyze the recovery implementation for domestic violence victims in Indonesia using the literature review method. The recovery implementation of domestic violence victima is carried out by building communication between relevant stakeholders so that cooperation is established in providing services to victims of domestic violence in accordance with their respective duties and responsibilities. The participation of external parties such as NGOs or women's organizations can assist in providing protection and assistance so that victims can still benefit from the policy even though there are still limitations from the government. The benefits of counseling services can help victims to grow confidence in living life. Empowerment through training can provide provisions for a more independent life. Obstacles faced by the government include: limited budget for handling cases of violence, especially violence against women; the number of assistants and counselors in some areas is still lacking; many room of special service facilities are inadequate and the distribution of safe houses is not evenly distributed in each area.
\end{abstract}

Keywords: Implementation of Policy, Domestic Violence, Recovery

\section{INTRODUCTION}

Domestic violence is a crime against humanity and an act of discrimination against women (Badan Diklat Kejaksaan, 2019). Women are more victims of domestic violence than men (Miller \& McMaw, 2019; Gulati \& Kelly, 2020; Komnas Perempuan, 2020). One in four women and one in ten men experience partner violence (Breiding et al., 2014; Miller \& McMaw, 2019). The United States' National Intimate Partner and Sexual Violance Survey (NISVS) noted that a third of women (37.3\%) and men (30.9\%) had experienced sexual violence, physical violence and stalking by a partner and $23.2 \%$ of women experienced violence. physical violence, while men experienced physical violence as much as 13.9\% (Breiding et al., 2014; Devries et al., 2013).

In Indonesia, the most common forms of violence are

\section{$\overline{1,2,3}$ Universitas Lampung \\ *) corresponding author}

Yudha Suchmasasi

Magister of Administration, Faculty of Social and Politic Science, University of Lampung

Jl. Prof. Sumantri Brojonegoro No. 1, Rajabasa, Bandar Lampung, Lampung, Indonesia

Email: suchmasasi@gmail.com physical violence, sexual violence, psychological violence and economic neglect. The following is data on the types of violence received by women in the personal sector:

Percentage of Forms of Violence Againts Women in The Personal/ Domestic Domain

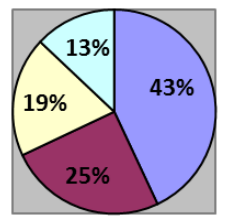

\begin{tabular}{|l|}
\hline$\square$ Physical \\
$\square$ Sexual \\
$\square$ Psychological \\
$\square$ Economic
\end{tabular}

Figure 1. Diagram of the Forms of Violence Against Women in the Personal Area/ Domestic Violence Source: Researcher Processed from Komnas Perempuan's 2020 Annual Records Data.

Based on the figure, it can be seen that the majority of women received physical violence, with a percentage of $43 \%$ ( 4,783 cases). Then $25 \%$ of sexual violence $(2,807$ cases), 2,056 cases of psychological violence (19\%) and 1,459 cases of economic violence or $13 \%$ (Komnas Perempuan, 2020).

Addressing domestic violence is a global public health priority because the prevalence of domestic violence is associated with physical and psychological morbidity and mortality (World Health Organization, 2013). Victims of domestic violence often get physical and psychological 
injuries that can interfere with the victim's activities. Therefore, it is important to pay attention to the victim's recovery in order to reduce the potential for medical and psychological trauma experienced by the victim.

Recovery of victims of domestic violence is directed at restoring the victim's condition to its original state, both physically and psychologically in a not too long time so that victims can carry out their daily activities and can live in the community as before. Recovery focuses on meeting the needs of victims due to the suffering and losses experienced by victims of domestic violence. Here the government's role is needed to take part in providing recovery for victims of domestic violence. Law No. 23 of 2004 article 10, states that victims of domestic violence are entitled to health services, special treatment, assistance by social workers and spiritual guidance services.

The government issued a special policy that regulates cooperation in the recovery of victims of domestic violence, which is stated in Government Regulation No. 4 of 2006 concerning the implementation and cooperation of recovery for victims of domestic violence. It was explained that the recovery of victims was all efforts to strengthen victims of domestic violence to be more empowered, both physically and psychologically. Therefore, the implementation of recovery includes all acts of service and assistance to victims carried out by health workers, social workers, companion volunteers and/or spiritual guides.

Based on this description, this article aims to describe and analyze the implementation of the policy for the recovery of victims of domestic violence in Indonesia.

\section{METHOD}

This article is a library research or literature review. Literature study is a series of activities related to collecting library data, reading and taking notes and processing research materials (Zed, 2014). The approach used is qualitative with descriptive analysis method. The qualitative approach was chosen because it aims to gain an in-depth, authentic and fundamental understanding of the phenomenon being observed. Descriptive analysis method is used because the data and information collected focuses on the actual phenomenon or problem through the process of collecting data, compiling, processing and drawing conclusions. The results attempt to describe an objective empirical state of the phenomenon or problem being studied.

Data collection techniques are carried out by searching, collecting, and studying the written material. Data searches were carried out via the internet using research databases, institutional websites, online media websites and through reading books or e-books. The research data base used to search for published articles is Science Direct, Scopus, Google Search, and Google Sholar. The application used is publish or perish 7, and google chrome. Keywords used to search for journal articles are domestic violence, elimination of domestic violence, prevention of violence, protection of violence, recovery of victims of violence. These keywords are used in Indonesian and English. The literature used is articles or journals published in 20112021 which can be accessed in full text in pdf format and scholarly (peer reviewed journals) using Indonesian and English.

Journals that match the inclusion criteria are then collected and a journal summary is made including: name of researcher, year of publication, research title, method and summary of results. The summary of the journal is entered into a table and then analyzed against the contents contained in the objectives and results of the study. The data analysis technique in writing this article takes the theory from Creswell (2016: 254-263) who stacks his techniques on organizing data, reading (taking notes), describing, clarifying, interpreting data into codes and themes, conclusions.

\section{RESULTS AND DISCUSSION}

\section{Communication Between Stakeholders}

Since advocacy was carried out during the drafting of the Draft Bill on the Elimination of Domestic Violence, efforts to recover victims of domestic violence have become an inseparable part of the legal process. This has become a shared responsibility between the government and service providers, both medical, psychological, legal and safe house services.

Government Regulation Number 4 of 2006 concerning Implementation of Recovery Cooperation for Victims of Domestic Violence explains that Recovery is an integrated effort to restore a person's condition after becoming a victim of domestic violence so that it requires the involvement and cooperation of various parties such as health workers, social workers, companion volunteers and/or spiritual guide, which in its implementation cooperates in a systematic and integrated manner. Basically, this Government Regulation aims to ensure the implementation of service facilities for domestic violence victims and the creation of good cooperation and coordination in the recovery of domestic violence victims between agencies, between implementing officers and between other related institutions (explanation of PP No. 4 of 2006).

The following is a table of the implementation of recovery activities for victims of domestic violence based on scope and technicality based on Government Regulation No. 4 of 2006 article 4-5.

Many parties are involved in handling victims of domestic violence, so it is necessary to establish and/or develop an Integrated Service Center (PPT) to provide specific and comprehensive treatment for victims. An integrated service center was formed to provide easy services in the form of complaint services, health rehabilitation, social rehabilitation, legal assistance and social reintegration (PPA Regulation Number 5 of 2010). Some use a referral system, one-stop service, managed by the local government itself or in collaboration between the local government and NGOs (Aji, 2017). The integrated service center is better known as the Integrated Service Center for the Empowerment of Women and Children (P2TP2A). This institution has spread across all provinces in Indonesia. In its organizational structure, UPTD P2TP2A consists of functional officials and implementing officials such as a professional team consisting of advocates, clinical psychologists and assistants (kemenpppa.go.id).

The implementation of recovery for domestic violence victims is carried out by establishing cooperation between actors in providing services to victims (Hasyim, 2018; Setyaningrum \& Arifin, 2019; Rahmawati et al., 2018; Sitoresmi \& Amanah, 2012). This collaboration is carried out through coordination to provide handling according to their responsibilities if there are reports of domestic violence that come in. When there is a report of a victim of domestic violence at the police station, an examination will be carried out on the condition of the victim. If the victim 
experiences physical violence and requires medical treatment, the victim will be referred to a hospital that is a referral place. Then the health team will check the victim's physical condition, the clinical psychological officer will also carry out a psychological examination of the victim. If the victim needs medical treatment, then the health worker will provide treatment services and restore the victim's health. Then assistance is provided by providing counseling, therapy, spiritual guidance and advocacy to strengthen and recover victims (Ramadhon \& Gorda, 2020).

Through good coordination between stakeholders involved, victims of domestic violence can be handled properly in the recovery process (Utami, 2016). The better the communication between the parties involved in an implementation process, the less chance of error (van Metter \& van Horn, 1975). Effective implementation occurs when the implementers already know what they have to do. Knowledge of what they have to do can work if communication is done well (Edward III, 1980). Through communication, messages or information will reach related parties so that there is an agreement between parties in understanding their responsibilities (Puspawati, 2018).

Table 1.

Implementation of Recovery Activities for Domestic Violence Victims

\begin{tabular}{|c|c|c|c|}
\hline $\begin{array}{l}\text { Institusi Penanggung } \\
\text { Jawab }\end{array}$ & Profession & Services provided & $\begin{array}{l}\text { Places to Provide } \\
\text { Services }\end{array}$ \\
\hline $\begin{array}{l}\text { Ministry of Women's } \\
\text { Empowerment, } \\
\text { Women's } \\
\text { Empowerment Sector }\end{array}$ & - & $\begin{array}{l}\text { a. Establish guidelines for the recovery of } \\
\text { domestic violence victims that are } \\
\text { gender sensitive } \\
\text { b. Coordinate with relevant agencies } \\
\text { c. Monitoring, evaluating and improving } \\
\text { recovery performance }\end{array}$ & - \\
\hline $\begin{array}{l}\text { Ministry of Health, } \\
\text { Department of Health }\end{array}$ & $\begin{array}{l}\text { Doctor/ Paramedic/ } \\
\text { Health worker }\end{array}$ & $\begin{array}{l}\text { a. Health services: physical/psychological } \\
\text { recovery of victims; } \\
\text { b. Create medical records } \\
\text { c. Victim assistance }\end{array}$ & $\begin{array}{l}\text { Health facilities owned } \\
\text { by the government, } \\
\text { local government and } \\
\text { the community }\end{array}$ \\
\hline $\begin{array}{l}\text { Department of Social } \\
\text { Affairs, Department of } \\
\text { Social Affairs }\end{array}$ & $\begin{array}{l}\text { Social worker/ } \\
\text { volunteer assistant/ } \\
\text { psychologist/ } \\
\text { spiritual guide }\end{array}$ & $\begin{array}{l}\text { a. Assistance in victim services: providing } \\
\text { counseling, therapy, spiritual guidance, } \\
\text { advocacy for the strengthening and } \\
\text { recovery of victims } \\
\text { b. Victim resocialization }\end{array}$ & $\begin{array}{l}\text { Safe house, service } \\
\text { center or alternative } \\
\text { residence owned by } \\
\text { the government, local } \\
\text { government or } \\
\text { community property }\end{array}$ \\
\hline $\begin{array}{l}\text { Police of the Republic of } \\
\text { Indonesia, Women and } \\
\text { Children Protection Unit }\end{array}$ & $\begin{array}{l}\text { Police Investigating } \\
\text { Officer/Policewoman }\end{array}$ & $\begin{array}{l}\text { a. A place to report and process } \\
\text { perpetrators of domestic violence crimes } \\
\text { to the prosecutor's office } \\
\text { b. Conduct counseling and assistance }\end{array}$ & $\begin{array}{l}\text { Special service room } \\
\text { (Women and Children } \\
\text { Service Unit) }\end{array}$ \\
\hline
\end{tabular}

\section{Partisipation of Multi Stakeholder}

Cooperation for the recovery of domestic violence victims is also carried out through coordination between relevant agencies and communities/institutions that care about eliminating domestic violence. This is regulated in chapter III of PP No. 4 of 2006. For the implementation of recovery, the government and local governments in accordance with their respective duties and functions can cooperate with the community or social institutions, both nationally and internationally.

The majority of local governments cooperate with other stakeholders outside the implementing agency. For example, the Semarang City government collaborates with NGOs that are concerned with gender realization and equality, namely the Legal Resource Center-Gender Justice and Human Rights (LRC-KJHAM) to provide counseling services (Muttaqin et al., 2016). Cooperation with the community or social institutions is carried out because the government has limitations in providing services to victims of domestic violence. As is the case in Cimahi City, the existing P2TP2A still have limited human resources and facilities so they collaborate with the Family Welfare Consultation Institute (LK3) to provide assistance to victims of domestic violence (Nuradhawati, 2018). Assistance is provided to heal trauma and resolve cases experienced by victims. Victims who have recovered will be directed to participate in social welfare efforts. Therefore, collaboration with Courses and Training
Institutions is needed (Sitoresmi \& Amanah, 2012; Rahmawati et al., 2018).

In addition, there is the involvement of NonGovernmental Organizations (NGOs) in providing protection and assistance to victims of domestic violence, especially for women and children. For example, the Sukowati Women's Care Alliance, the Merangin Women's Alliance, Rifkah Annisa, and others. These organizations provide recovery services through a guidance and counseling approach to help strengthen and empower victims of domestic violence, especially women (Hariyanto, 2016; Hamirul \& Nazir, 2019; Saputri \& Khairi, 2020).

The cooperation and involvement of organizations outside the implementing agency can assist the government in providing recovery services for victims of domestic violence, considering that there are still limitations on the part of the government so that it requires the involvement of other parties. The participation of external stakeholders in providing support for activities can encourage the successful implementation of programs or activities (Sulistyorini, 2018). Synergized public support can encourage the achievement of the goals that have been set (Puspawati et al., 2020). The success of policy operationalization is strongly influenced by stakeholders or stakeholders either as subject or object of policy (Mahfud et al., 2015). Mazmanian \& Sabatier (1983) stated that there are opportunities that are open for actors outside the implementing agency to participate in the implementation of policies to support the objectives to be achieved. 


\section{Benefits of policy}

Recovery of victims of domestic violence is directed at restoring the victim's condition to normal, both physically and psychologically, so that victims can carry out their daily activities and can live in the community as before. The recovery carried out through counseling activities has the aim of raising awareness to the victim that he is not an object that can be treated arbitrarily; provide reinforcement for victims to be optimistic because they have the potential to be better; and growing awareness and understanding that domestic violence that mostly affects women is wrong behavior, behavior that is not in accordance with social values. Provide counseling services that are very helpful for victims of domestic violence who can be said to have entered the hopeless phase.

Apart from counseling, assistance activities for recovery can be carried out through empowerment and social rehabilitation. Victims of domestic violence who have started to improve will be directed to participate in social welfare efforts through training activities with the aim of providing busyness and providing skills to earn income after participating in the training so that victims can be independent and not economically dependent, especially wives to their husbands. Through the improvement of these skills, women will be given skills that can be used to improve the social welfare of the family which in turn can improve recovery.

There is a change in the victim's attitude and psychological after receiving counseling services. Victims feel relieved and not psychologically depressed, grow confidence in living life and have the motivation to be more independent (Muttaqin et al., 2016). The benefits of empowerment through training can also be used as a provision to not be economically dependent on a partner. It can be seen from the results of the study that as many as 80 percent of respondents have sufficient/good recovery power (Sitoresmi \& Amanah, 2012).

The policy to provide recovery for victims of domestic violence provides good benefits for victims so that victims can carry out their activities properly as before the occurrence of domestic violence. According to (Grindle, 1980) that the success of policy implementation is determined by the level of implementability consisting of content of policy and context of policy. Benefits are included in the content of policy: a policy must provide benefits that show a positive impact.

\section{Resources In The Implementation of Recovery}

\section{Facility}

Government Regulation No. 4 of 2006 paragraph 2 states that special service rooms in the police, service centers and safe houses include facilities needed for victim recovery. Room of Special Service (RPK), which is a safe and comfortable room for criminal victims, especially women who need special treatment when the case is being handled by the police. The purpose of establishing the RPK is to provide special services and protection handled by the PPA Unit. RPK is equipped with living room facilities, counseling room, control room and rest room which is supported with complete equipment (Regulation of the Chief of the Indonesian National Police No. 3 of 2008).

However, RPK facilities for female and child victims are still minimal. According to the Head of the PPA Unit Bareskrim Polri that ideally every PPA unit has an RPK supported by waiting room facilities, a separation room between victims and perpetrators and a control room, but due to limited land and budget, the RPK development is uneven and the facilities are incomplete (tirto.id, April 24 2019).

One of the important elements of a crisis center for women and children victims of domestic violence is the availability of shelter services or safe houses, namely temporary shelters for women and children victims of violence whose lives are threatened or require intensive treatment due to the violence experienced. Safe houses or shelters as an important need for women and children victims of violence have also become an important part or element of P2TP2A as a crisis center developed by the government.

The existence of government-owned safe houses is not evenly distributed in each regional service unit. There are several areas that still do not have safe houses to provide protection and services to victims and several other areas already have safe houses with fairly good facilities (Utami, 2016; Nuradhawati, 2018; Jaftoran \& Alputila, 2019; Abdullah, 2019). Safe house service is one form of law enforcement, namely providing protection and fulfillment of the rights of victims provided by P2TP2A.

Indirectly, the availability of facilities will affect law enforcement (Eleanora \& Putri, 2020). According to Edward III (1980), without supporting facilities (facilities and infrastructure) it is difficult to achieve success in implementing policies. When facilities are not available, problems arise to achieve the desired goals (van Metter \& van Horn, 1975).

\section{Human Resources}

Assistance in recovery activities for victims of domestic violence is carried out through counseling, psychological therapy, advocacy and spiritual guidance carried out by health workers, social workers, companion volunteers and spiritual mentors (Article 1 Government Regulation No. 4 of 2006). Therefore, in every integrated service center it is necessary to have a professional team to provide services in accordance with their duties and responsibilities. For example, the medical profession has a duty to provide support in overcoming this problem by providing a public health approach to support the most vulnerable in society (Chandan et al., 2020).

However, the availability of human resources in several service centers, especially those in the Regency is still lacking so that it is not uncommon to provide services, they must be referred to service centers in the province with more complete resources (Tribunlampungwiki.tribunnews.com, 2021). The majority of HR constraints are related to the number of assistants and counselors or clinical psychologists who are not proportional to the number of victims who must be served (Fadlurrahman, 2014; Rosnawati, 2017). There are even service centers that do not yet have psychologists to provide assistance in assisting victims due to budget constraints so as to provide psychological counseling and therapy services in collaboration with other institutions such as the Family Welfare Consultation Institute (Nuradhawati, 2018). Provide counseling services that are very helpful for victims of domestic violence who can be said to have entered the hopeless phase. The provision and expansion of psychiatric services plays an important role in providing mental treatment and providing support to victims (Gulati \& Kelly, 2020).

The human resources (staff) who work in the integrated service center or P2TP2A have not been proportional to the number of victims of violence that must be handled, causing the provision of services to 
victims of domestic violence, especially women and children, has not been optimal. According to Edward III (1980), failures that often occur in policy implementation are caused by inadequate or inadequate staff. The number of human resources that are not proportional to the tasks carried out will be a gap in policy implementation because it is difficult to carry out all tasks optimally (Puspawati, 2018).

\section{Budget}

All costs for the implementation of recovery for victims of domestic violence carried out by the government and local governments are charged to the State Revenue and Expenditure Budget (APBN), and the Regional Revenue and Expenditure Budget (APBD) as well as other legal sources according to regulations (article 22 PP no. 4 of 2006) .

Handling victims of violence requires a large budget because it is not only a matter of assistant staff such as counselors, psychologists, health workers and so on but also operations such as the operation of safe houses which include buildings and operational costs including referral costs and medical intervention. The amount of this cost is not balanced with the maximum budget policy. The budget for handling cases of violence against women is very small when compared to other budgets (Hafidhoh \& Yuliana, 2015: 32). This causes the availability of facilities and human resources is limited.

Lack of funding or budget sources can cause problems in implementing policies (Puspawati, 2018) because the budget is a vital supporting factor in the implementation of public policies (Mazmanian \& Sabatier, 1983). An unavailable budget will cause problems to realize policy objectives (van Metter \& van Horn, 1975).

\section{CONCLUSIONS AND RECOMMENDATIONS}

The implementation of recovery for domestic violence victims is carried out by establishing communication with relevant stakeholders so that cooperation is established in providing services to victims of domestic violence in accordance with their respective duties and responsibilities. The existence of access from outside parties in this case participating NGOs or women's observer organizations can assist in providing protection and assistance to victims of domestic violence and support the goals to be achieved. The impact of this good cooperation, the policy to provide recovery for victims of domestic violence provides good benefits for victims so that victims can carry out their activities without psychological pressure and have the motivation to be more independent. However, there are still some problems in terms of resources, namely: limited budget for handling cases of violence, especially violence against women, the number of assistants and counselors in some areas is still lacking, many room of special service facilities are not adequate and the distribution of safe houses is not evenly distributed in each area.

\section{REFERENCES}

Abdullah, M. (2019). Rumah Aman Bagi Korban Kekerasa dalam Rumah Tangga Terhadap Perempuan Di Aceh (Studi Kasus P2TP2A Provinsi Aceh). Jurnal Dusturiah, 9(2), 179209.
Badan Diklat Kejaksaan. (2019). Modul penghapusan kekerasan dalam rumah tangga. Badan Diklat Kejaksaan RI.

Breiding, M. J., Chen, J., \& Black, M. C. (2014). Intimate Partner Violence in the United States - 2010. In Centers for Disease Control and Prevention. National Center for Injury Prevention and Control, Centers for Disease Control and Prevention.

https://www.cdc.gov/violenceprevention/pdf/cdc_nisvs_ip v_report_2013_v17_single_a.pdf

Chandan, J. S., Taylor, J., Bradbury-Jones, C., Nirantharakumar, K., Kane, E., \& Bandyopadhyay, S. (2020). COVID-19: a public health approach to manage domestic violence is needed. The Lancet Public Health, 5(6), e309. https://doi.org/10.1016/S2468-2667(20)30112-2

Creswell, J. W. (2016). Research Design Pendekatan Metode Kualitatif, Kuantitatif dan Campuran (Edisi 4). Pustaka Pelajar.

Devries, K. M., Mak, J. Y. T., García-Moreno, C., Petzold, M., Child, J. C., Falder, G., Lim, S., Bacchus, L. J., Engell, R. E., Rosenfeld, L., Pallitto, C., Vos, T., Abrahams, N., \& Watts, C. H. (2013). The Global Prevalence of Intimate Partner Violence Against Women. Science, 340(6140), 1527-1528. https://doi.org/10.1126/science.1240937

Edward III, G. (1980). Implementing Public Policy. Congresional Quarterly Press.

Eleanora, F. N., \& Putri, E. A. (2020). Telaah Kritis Upaya Penegakan Hukum Terhadap Tindak Pidana Kekerasan Dalam Rumah Tangga. Borneo Law Review Journal, 4(1), 21-30.

http://180.250.193.171/index.php/bolrev/article/viewFile/ $1395 / 953$

Fadlurrahman, L. (2014). Kinerja Implementasi Kebijakan Penanganan Perempuan Korban Kekerasan. Jurnal Kebijakan Dan Admisitrasi Publik, 18(2), 161-184. https://doi.org/10.22146/jkap.7520

Grindle, M. . (1980). Politics and Policy Implementation in The Third World. PrincentonUniversity Pres.

Gulati, G., \& Kelly, B. D. (2020). Domestic violence against women and the COVID-19 pandemic: What is the role of psychiatry? International Journal of Law and Psychiatry, 71,101594. https://doi.org/10.1016/j.ijlp.2020.101594

Hafidhoh, N., \& Yuliana, I. (2015). Kewajiban Minus Konsekuensi Anggaran. LRC KJHAM Semarang.

Hamirul, \& Nazir, M. (2019). Lembaga Swadaya Masyarakat Aliansi Perempuan Merangin Untuk Kekerasan Dalam Rumah Tangga. Jurnal Marketing, 3(1), 173-193.

Hariyanto, L. (2016). Pelaksanaan Pendampingan Konseling Di Rifka Annisa Dalam Pemberdayaan Perempuan Korban Kekerasan Dalam Rumah Tangga (KDRT). Jurnal Elektronik Mahasiswa Pend. Luar Sekolah, 5(7), 231-239.

Hasyim, N. (2018). Menyoal Pemulihan Anak Korban Kekerasan di Indonesia. PALASTREN Jurnal Studi Gender, 10(2),

https://doi.org/10.21043/palastren.v9i2.2049

Jaftoran, F., \& Alputila, M. J. (2019). Perlindungan Hukum Terhadap Perempuan Sebagai Korban Kekerasan dalam Rumah Tangga Ditinjau dari Undang-Undang No.23 Tahun 2004 Tentang Penghapusan Kekerasan dalam Rumah Tangga. Jurnal Restorative Justice, 2(2), 164-174.

Komnas Perempuan. (2020). Kekerasan meningkat: Kebijakan penghapusan kekerasan seksual untuk membangun ruang aman bagi perempuan dan anak perempuan. In Catahu: Catatan tahunan tentang kekerasan terhadap perempuan. 
https://www.komnasperempuan.go.id/file/pdf_file/2020/C atatan Tahunan Kekerasan Terhadap Perempuan 2020.pdf

Mahfud, M. A., Haryono, B. S., \& Anggraeni, N. L. V. (2015). Peran Dan Koordinasi Stakeholder Dalam Pengembangan Kawasan Minapolitan Di Kecamatan Nglegok, Kabupaten Blitar. Jurnal Administrasi Publik, 3(12), 2070-2076.

Mazmanian, D. H., \& Sabatier, paul A. (1983). Implementation and Public Policy. Harper Collins.

medcom.id. (2019). Minimnya Fasilitas Pelayanan Perempuan dan Anak di Kantor Polisi - Medcom.id. Medcom.Id. https://www.medcom.id/nasional/peristiwa/GNl2BrPkminimnya-fasilitas-pelayanan-perempuan-dan-anak-dikantor-polisi

Miller, E., \& McMaw, B. (2019). Intimate Partner Violence. The New England Journal of Medicine, 850-857. https://doi.org/10.1056/NEJMra1807166

Muttaqin, M. A., Murtadho, A., \& Umriana, A. (2016). Bimbingan Konseling Bagi Perempuan Korban Kekerasan Dalam Rumah Tangga di LRC-KJHAM Semarang. Jurnal Sawwa, 11(2), 177-210.

Nuradhawati, R. (2018). Peran Pusat Pelayanan Terpadu Pemberdayaan Perempuan dan Anak (P2TP2A) dalam Pendampingan Perempuan dan Anak Korban Kekerasan dala Rumah Tangga (KDRT) di Kota Cimahi. Jurnal Academia Praja, 1(1), 149-184.

Peraturan Kepala Kepolisian Negara Republik Indonesia Nomor 10 Tahun 2007 Tentang Organisasi dan Tata Kerja Unit Pelayanan Perempuan dan Anak (Unit PPA) di Lingkungan Kepolisian Negara Republik Indonesia.

Peraturan Menteri Pemberdayaan Perempuan dan Perlindungan Anak Republik Indonesia Nomor 5 Tahun 2010 Tentang Panduan Pembentukan dan Pengembangan Pusat Pelayanan Terpadu.

Peraturan Pemerintah Nomor 4 tahun 2006 Tentang Penyelenggaraan dan Kerjasama Pemulihan Korban Kekerasan Dalam Rumah Tangga.

Puspawati, A. A. (2018). Gap Implementasi Kebijakan Keluarga TKI di Kabupaten Malang. Jurnal Wacana Publik, 12(2).

Puspawati, A. A., Sumartono, Haryono, B. S., \& Setyowati, E. (2020). Stakeholder Analysis on The Implementation of Family Development Program for Indonesian Migrant Workers Using Soft System Methodology. Eurasia: Economic \& Business, 11(41), 25-34. https://doi.org/DOI https://doi.org/10.18551/econeurasia.2020-11

Rahmawati, R., Sukidin, S., \& Suharso, P. (2018). Pemberdayaan Perempuan Korban Kekerasan Dalam Rumah Tangga (KDRT) Oleh Dinas Pemberdayaan Perempuan, Perlindungan Anak Dan Keluarga Berencana (DP3AKB) Kabupaten Jember. JURNAL PENDIDIKAN EKONOMI: Jurnal IImiah IImu Pendidikan, IImu Ekonomi Dan IImu Sosial, 12(2), 162-167. https://doi.org/10.19184/jpe.v12i2.8305

Ramadhon, S., \& Gorda, T. R. (2020). Perlindungan Hukum Terhadap Perempuan Sebagai Korban Kekerasan Dalam Rumah Tangga Secara Preventif dan Represif. Jurnal Analisis Hukum, 3(2), 205-217.

Rosnawati, E. (2017). Perlindungan Terhadap Korban Kekerasan dalam Rumah Tangga di Kabupaten Sidoarjo Pasca Berlakunya UU Nomor 23 Tahun 2004. Halu Oleo Law Review (Horlev), 1(1), 86-104. https://doi.org/doi.org/10.33561/holrev.v1i1.2352

Saputri, N. D., \& Khairi, A. M. (2020). Bimbingan Islami Untuk Menangani Trauma Korban Kekerasan Dalam Rumah Tangga Di Aliansi Peduli Perempuan Sukowati Sragen.
Academic Journal of Psychology and Counseling, 1(1), 4659.

Setyaningrum, A., \& Arifin, R. (2019). Analisis Upaya Perlindungan dan Pemulihan Terhadap Korban Kekerasan Dalam Rumah Tangga ( Kdrt ) Khususnya Anak-Anak. Jurnal Ilmiah Muqoddimah, 3(1), 9-19. https://doi.org/http://dx.doi.org/10.31604/jim.v3i1.2019.919

Sitoresmi, N., \& Amanah, S. (2012). Pendampingan Perempuan Korban Tindak Kekerasan Oleh Pusat Pelayanan Terpadu Pemberdayaan perempuan dan Anak (P2TP2A). Sosiologi Pedesaan, 06(03), 260-271.

Sulistyorini, S. (2018). Partisipasi Stakeholder Eksternal dalam Meningkatkan Mutu Pendidikan di Sekolah Dasar. Ta'allum: Jurnal Pendidikan Islam, 6(2), 347-372. https://doi.org/10.21274/taalum.2018.6.2.347-372

tirto.id. (2019). Fasilitas RPK untuk Anak dan Perempuan di Kantor Polisi Masih Minim. Tirto.Id. https://tirto.id/fasilitas-rpk-untuk-anak-dan-perempuandi-kantor-polisi-masih-minim-dm32

Tribunlampungwiki.tribunnews.com. (2021). Potret UPTD PPA Provinsi Lampung, Lembaga Perlindungan Perempuan dan Anak di Lampung. Tribunnews.Com. https://tribunlampungwiki.tribunnews.com/2021/02/06/p otret-uptd-ppa-provinsi-lampung-lembaga-perlindunganperempuan-dan-anak-di-lampung?page=all

Undang-Undang Nomor 23 Tahun 2004 Tentang Penghapusan Kekerasan Dalam Rumah Tangga.

Utami, P. N. (2016). Optimalisasi Pemenuhan Hak Korban Kekerasan Terhadap Perempuan Melalui Pusat Pelayanan Terpadu. Jurnal HAM, オ1), 55-67. https://doi.org/10.30641/ham.2016.7.71

van Metter, D., \& van Horn, C. E. (1975). The Policy Implementation Process: A Conceptual Framework. Administration and Society, 5(4), 445-485.

World Health Organization. (2013). Global and Regional Estimates of Violance Againts Women: Prevalence and Health Effect of Intimate Partner Violance and Non-Partner Sexual Violance. https://apps.who.int/iris/bitstream/handle/10665/85239/9 789241564625_eng.pdf?sequence=1\&isAllowed=y

Zed, M. (2014). Metode Penelitian Kepustakaan. https://books.google.co.id/books/about/Metode_Penelitian _Kepustakaan.html?id=zG9sDAAAQBAJ\&printsec=frontcov er\&source=kp_read_button\&redir_esc $=\mathrm{y} \# \mathrm{v}=$ onepage \&q\&f= false 